Egyptian Journal of Rabbit Science, 25(2): 149 - 168(2015)

\title{
THE INFLUENCE OF ADDITION SOME MEDICAL AND AROMATIC PLANTS TO GROWING RABBIT DIETS. 1- INFLUENCE ON GROWTH PERFORMANCE, DIGESTIBILITY, BLOOD CONSTITUENTS AND ECONOMICAL EFFICIENCY
}

\author{
M. M. El-Adawy*, M. H. Khodeir**, Zahraa R. Abou El-Ezz* and \\ Omaima A. A. Al-Shamandy** \\ * Department of Animal and Fish Production, Faculty of Agriculture, \\ Alexandria University, Alexandria, Egypt \\ ** Veterinary Serum and Vaccine Research Institute, Abassia, Cairo, Egypt
}

A total of forty New Zealand White (NZW) male rabbits of 6 weeks of age with an average initial body weight $83766 \pm 42.4 \mathrm{~g}$ were used to study the effects of medicinal and aromatic plants supplementation on growth performance, digestibility of nutrients, chemical composition of soft and hard feces, carcass traits, some blood plasma constituents and economical efficiency. Rabbits were distributed into 5 groups of eight rabbits each. The first group received basal unsupplemented diet which served as control diet, while the P1, P2, P3 and P4 groups were supplemented with $1.0 \%$ Basil, Chamomile, Fennel or Ginger, respectively.

Results showed that the final body weight (13 weeks of age), daily weight gain and performance index significantly $(P<0.05$ or 0.01$)$ increased in group fed diet supplemented with 1.0\% fennel (P3), while the lowest values were obtained in rabbits fed diet supplemented with $1.0 \%$ ginger (P4). Rabbits fed diet P3 (1.0\% fennel) showed significantly $(P<0.01)$ the highest daily feed intake (88.85 g/day) comparing with the other experimental groups. The lowest feed intake was obtained in rabbits fed diet supplemented with $1.0 \%$ ginger (P4). Also, the rabbits fed diet $P 3$ $(1.0 \%$ fennel) showed better $(P<0.01)$ feed conversion ratio (3.35) than those fed the control or other experimental diets. Digestibility values and feeding values such as TDN, DCP and ME were significantly higher $(P<0.05$ or 0.01$)$ with fennel and chamomile supplementation diets (groups $P 2$ and P3) than those of the control or other experimental groups. Rabbits fed diets supplemented with $1.0 \%$ basil, chamomile or fennel excreted higher crude protein in soft feces and lower in hard feces than those fed the control or ginger supplemented diets. The highest $(P<0.05)$ crude fiber content of soft feces was observed in groups fed the control and ginger supplemented diets (diets $C$ and $P 4)$, while the lowest $(P<0.05)$ crude fiber content was obtained in groups fed basil and fennel 
supplemented diets (P1 and P3 groups). Carcass traits were insignificantly affected by tested supplementation, except the dressing\%, hot and cold weight. The highest economical efficiency value was recorded in group fed diet P3 supplemented with $1.0 \%$ fennel, followed by those fed P2 diet supplemented with $1.0 \%$ chamomile. The lowest economical efficiency value was recorded in group fed diet P4 supplemented with $1.0 \%$ ginger.

Conclusively, it is concluded that the supplementation of growing rabbit diets with $1.0 \%$ fennel or chamomile caused relatively considerable improvement in the growth performance without negative effects on carcass characteristics and constituents of blood plasma. Meanwhile, $1.0 \%$ fennel supplementation in growing rabbit diets resulted in the best economical efficiency (\%).

Key words: Rabbits, medical \& aromatic plants, growth performance, digestibility, carcass \& blood serum constituents.

Animal feed additives are used worldwide for many different reasons. Some help to cover the needs of essential nutrients and others to increase growth performance, feed intake and therefore optimize feed utilization. The health status of animals with a high growth performance is a predominant argument in the choice of feed additives. The use of feed additives is more and more questioned by the consumers. Therefore, the feed industry is highly interested in valuable alternatives which could be accepted by the consumers. Probiotics, prebiotics, enzymes and highly available minerals as well as herbs can be seen as alternatives (Caspar Wenk, 2003).

Herbs have been used as food and for medicinal purposes for centuries. Several herbal products that may enhance the function of the immune system are available. In different herbs, a wide variety of active phytochemicals, including the flavonoids, terpenoids, lignans, sulfides, polyphenolics, carotenoids, coumarins, saponins, plant sterols, curcumins and phthalides have been identified (Cross et al., 2007). Herbs, spices and their extracts (botanicals) have a wide range of activities. They can stimulate feed intake and endogenous secretions or have antimicrobial, coccidiostatic or anthelmintic activity. A major field of application of herbs is the protection of animals and their products against oxidation (Caspar Wenk, 2003).

Medicinal plants have been traditionally sourced for the treatment of various diseases, in both humans and animals. A number of dietary herbs, plant extracts and essential oils have been studied for their antimicrobial and growth promoting abilities in mono gastric animals (Cross et al., 2007). The addition of 
medical plants in broiler diets, improved growth performance, feed conversion efficiency, meat quality and reduced the feed cost (Huang et al., 1992).

Therefore, the main target of the present study is to investigate the effect of supplementing rabbit diets with some medicinal and aromatic plants such as chamomile flower (Matricaria chamomilla), ginger (Zingiber officinale), Basil (Ocimum basilicum-L) or fennel (Foeniculum Vulgare), as natural growth promoters, on growth performance, nutrients digestibility, chemical composition of soft and hard feces, carcass traits, some blood plasma constituents and economical efficiency of growing New Zealand White rabbits from 6 to 13 weeks of age.

\section{MATERIALS AND METHODS}

The field part of the present study was carried out at Rabbit Research Laboratory (Abbis), while the chemical analysis was performed at the Nutrition Research Laboratory, belonging to the Animal and Fish Production Department (El-Shatby), Faculty of Agriculture, Alexandria University, Alexandria, Egypt. The study was carried out during the period from January to July, 2013.

A total of forty weanling New Zealand White male rabbits of 6 weeks of age with an average initial body weight $837.66 \pm 42.4 \mathrm{~g}$ were obtained from a local commercial farm. Rabbits were allotted at random among five experimental groups (eight rabbits each) with nearly similar means (insignificant differences) of live body weight. The first group was fed on the control diet (C), while groups P1, P2, P3 and P4 were fed on the control diet supplemented with $1.0 \%$ basil, chamomile, fennel or ginger, respectively, ( $99 \%$ control diet $+1 \%$ of the tested materials). The formulation and chemical analysis of the control diet is summarized in Table 1. A commercial vitamin and mineral premix was added for all the experimental diets. Animals were individually caged in metal galvanized cages under the same managerial conditions in a well ventilated block building. Fresh air circulated in the house using exhaust fans. Temperature during the experimental periods varied between 16 and $22{ }^{0} \mathrm{C}$ employing electrical heaters. The rabbits were kept within a cycle of $16 \mathrm{~h}$ light and $8 \mathrm{~h}$ dark using artificial light. Fresh water was automatically available all the time by stainless steel nipples for each cage. The experimental diets were offered to rabbits ad libitum in pelleted form. Live body weight $(\mathrm{g})$ and daily feed consumption $(\mathrm{g})$ were individually recorded each week up to 13 weeks of age (marketing age). Feed conversion ratio was calculated as $\mathrm{g}$ feed/g gain. Performance index $(P I)$ and relative growth rate $(R G R)$ were calculated according to North (1981) as given below:-

$$
\boldsymbol{P I}=[\text { live body weight }(\mathrm{kg}) / \text { Feed conversion }] \text { x } 100
$$


Table 1: Formulation and chemical analysis of the basal diet (control diet)

\begin{tabular}{lc}
\hline Ingredients & \% \\
\hline Egyptian berseem hay & 33.0 \\
Barley grain & 16.0 \\
Yellow corn & 12.0 \\
Wheat bran & 18.0 \\
Soybean meal (44\%) & 16.5 \\
Common salt & 0.5 \\
Molasses & 2.0 \\
Di-Calcium Phosphate & 0.5 \\
Limestone & 1.0 \\
Vitamin \& mineral premix* & 0.2 \\
DL-Methionine & 0.2 \\
Anti-toxicants & 0.1 \\
\hline Total & $\mathbf{1 0 0}$ \\
Chemical composition (\%) & \\
Dry matter (DM) & 92.69 \\
On DM basis (\%): & \\
Organic matter (OM) & 88.72 \\
Crude protein (CP) & 16.08 \\
Ether extract (EE) & 2.46 \\
Crude fiber (CF) & 10.44 \\
Nitrogen free extract (NFE) & 58.74 \\
Ash & 11.28 \\
DE (Kcal/kg feed DM)** & 2603.1 \\
\hline
\end{tabular}

*Vitamins and mineral premix per kilogram contained: Vit. A 2,000,000 I $\mu$, Vit. $\mathrm{D}_{3} 150,000$ $\mathrm{I} \mu$, Vit. K $0.33 \mathrm{mg}$, Vit. $\mathrm{B}_{1} 0.33 \mathrm{~g}$, Vit $\mathrm{B}_{2} 1.0 \mathrm{~g}$, Vit $\mathrm{B}_{6} 0.33 \mathrm{~g}$, Vit. B12 $1.7 \mathrm{mg}$, Pantathonic acid 3.33 g, Biotin $33 \mathrm{mg}$, Folic acid 0.83 g, Choline chloride $200 \mathrm{mg}, \mathrm{Zn} 11.7 \mathrm{~g}, \mathrm{Mn} 5.0 \mathrm{~g}, \mathrm{Fe}$ $12.5 \mathrm{~g}, \mathrm{Mg} 66.7 \mathrm{mg}$, Se $16.6 \mathrm{mg}$, Co $1.33 \mathrm{mg}$, Cu $0.5 \mathrm{~g}$, I $16.6 \mathrm{mg}$ and Antioxidant $10.0 \mathrm{~g}$. ** DE (Kcal/kg feed DM) was calculated according to Cheeke (1987).

$$
R G R=\frac{w 2-w 1}{1 / 2(w 1+w 2)} \times 100
$$

Whereas: $\quad \boldsymbol{W} \mathbf{1}=$ the initial weight, and $\boldsymbol{W} \mathbf{2}=$ the final body weight

Viability and the clinical health status of all rabbits were recorded daily and viability percentage was calculated as follows:-

Viability $\%=\frac{\text { Total number of live animals at the end }}{\text { Total number of animals at start }} \times 100$

Five digestibility and nitrogen balance trials were undertaken using a total of twenty rabbits (13 weeks of age) (four rabbit / group). The Rabbits were kept individually in metabolic cages that allow to collecting feces and urine separately. Rabbits of each group were offered one of the experimental diets. The trials lasted for 21 days, 14 days as a preliminary period for adaptation to 
experimental diets followed by 7 days for measurements of actual consumed feed and feces and urine output. Samples of daily feces (20\%) of each rabbit were collected every day, dried at $60-70{ }^{\circ} \mathrm{C}$ for $48 \mathrm{~h}$, bulked, mixed, finally ground and kept for chemical analysis. Urine was quantitatively collected for each animal and the volume was measured, then $0.1 \mathrm{ml}$ of concentrated hydrochloric acid was added to $10 \%$ sample of the urine before freezing and storing for chemical analysis.

Chemical composition of the basal diet, feces and urine were carried out according to A.O.A.C. (1995). The metabolizable energy (ME) values were calculated according to the equation described by Kalogen (1985) as follows: $\mathrm{ME}(\mathrm{Kcal} / \mathrm{kg} \mathrm{DM})=(0.588+0.164 \mathrm{X}) 239$

Where, $\mathrm{X}$ is the dry matter digestion of the offered diet.

Values of the total digestible nutrients (TDN\%) and the digestible crude protein (DCP\%) were calculated according to classic formula (Cheeke et al., 1982).

At the end of the digestibility trials (16 weeks), excretion of soft (SF) and hard feces (HF) were determined using three rabbits per treatment. Plastic neck collars were used to prevent caprophagy. Rabbits were kept in individual metabolic wire cages $(45 \times 45 \times 30 \mathrm{~cm})$ that allowed separation of feces and urine. The experimental diets were offered to rabbits ad libitum in pelleted form. Soft and hard feces were collected during 24 hours for three times according to the method described by Carabano et al. (1988). The daily feed intake was recorded after deducting the scattered amounts. Daily soft and hard feces of each rabbit were collected throughout 24 hours two times. Samples of daily soft and hard feces (20\%) of each rabbit were taken for chemical analysis. The daily feces collected samples were sprayed with $1 \%$ boric acid solution to prevent ammonia losses during drying. Feces samples were dried at $70-80^{\circ} \mathrm{C}$ for 48 hours. The dried feces samples from each rabbit during the collection period were mixed, ground and kept for chemical analysis. Chemical composition of hard and soft feces samples were analyzed according to A.O.A.C. (1990).

A total of fifteen rabbits (three rabbits / group) were randomly taken at $14^{\text {th }}$ weeks of age. Rabbits were kept off feed for 16 hours before slaughter. Blood samples were individually collected at slaughtering in non heparinized glass tubes (3 samples / treatment group). Plasma was separated within an hour after collection by centrifugation at 3000 r.p.m. for 20 minutes. Serum total protein and albumin were measured according to Armstrong and Carr (1964). Serum globulin was calculated by the difference between serum total protein and albumin. Serum total lipids and cholesterol were measured according to (Chabrol and Charonnat, 1973) and (Watson, 1960), respectively. 
After complete bleeding, the carcass traits were estimated. Carcass traits described by Blasco et al. (1992) were evaluated. Hot carcass weight (HCW) was obtained 15 to 30 minutes after slaughter including liver, kidneys and head besides: (lungs, esophagus, trachea, thymus and heart).

Dressing percentage (DP) was obtained as follows:

$$
D P=\frac{\text { Abdomen fat }+ \text { Giblets }+ \text { Carcass weight }+ \text { head }}{\text { Live weight }} \times 100
$$

Cold carcass weight $(\mathrm{CCW})$ was obtained after refrigerating the hot carcass at 4 ${ }^{\circ} \mathrm{C}$ for 24 hours. Drip loss percentage was calculated as [(HCW - CCW $\left.) / \mathrm{HCW}\right] \mathrm{x}$ 100. Giblets weight (liver, kidneys and spleen) and carcass measurements were obtained and their proportion to the live body weight was calculated. The economical efficiency was calculated by the following equation:-

$$
\mathrm{Y}=[(\mathrm{A}-\mathrm{B}) / \mathrm{B}] \mathrm{x} 100
$$

Where $\mathrm{A}$ is selling price of obtained gain and $\mathrm{B}$ is the feeding cost for this gain (cited by El-Kerdawy, 1997).

The data of the experiments were statistically analyzed using analysis of variance according to Statistical Analysis System (SAS 2004). and the Duncan's test (1955) was used to compare between each two means. The following model was assumed to describe an observation of the experiments:

$$
\mathrm{Y}_{\mathrm{ij}}=\mu+\mathrm{t}_{\mathrm{i}}+\mathrm{e}_{\mathrm{ij}}
$$

Where: $Y_{i j k}=$ an observation of each traits studied, $\mu=$ Overall mean, $t_{i}=$ Fixed effect of the $i^{\text {th }}$ treatment, $e_{i j}=$ the random error term associated with each observation and assumed independent, normally distributed with mean zero and variance $\delta 2 \mathrm{e}$.

\section{RESULTS AND DISCUSSION}

\section{Growth performance and feed utilization:}

Growth performance data of growing NZW rabbits as affected by dietary supplementation with different medical and aromatic plants $(1.0 \%$ basil, chamomile, fennel or ginger) are presented in Table 2. At 13 weeks of age, there were significant differences $(\mathrm{P}<0.01)$ among the experimental groups in final body weight, total and daily weight gain, daily feed consumption, and performance index. Growing rabbit performance was significantly improved $(\mathrm{P}<0.01)$ by the diets supplementation with $1.0 \%$ basil, chamomile or fennel. Dietary supplementation with $1.0 \%$ fennel $(\mathrm{P} 3)$ showed significantly $(\mathrm{P}<0.01)$ the highest final body weight, total and daily weight gain $(2125,1278$ and $26.07 \mathrm{~g}$, respectively), while, the dietary supplementation with $1 \%$ ginger (P4) significantly $(\mathrm{P}<0.01)$ decreased the final body weight by $17.34 \%$ than those fed the control diet. Srinivas Nammi et al. (2008) found that the ethanolic 
extract of ginger showed remarkable protection from the high-fat diet induced metabolic disturbances by strongly suppressing the body weight gain, protection from hyper glycaemic, hyper lipidaemic and insulin-resistant conditions.

Daily weight gain in groups fed diet P2 and P3 (supplemented with hamomile or fennel) were significantly increased $(\mathrm{P}<0.01)$ by 9.36 and $17.91 \%$ respectively, while the daily feed consumption were significantly $(\mathrm{P}<0.01)$ increased by $4.91 \%$ and $11.10 \%$ respectively, than those fed the control diet (C). These results support those found by Hanna et al. (2008) and Skomorucha et al. (2013) who reported that the body weight gain and feed consumption of growing rabbits were significantly improved by the $1.0 \%$ fennel or $0.75 \%$ chamomile dietary supplementation. Fennel and chamomile supplementation in rabbit diets improved significantly $(\mathrm{P}<0.05)$, both feed conversion and performance index up to 13 weeks old. On the other hand Omage et al. (2007) reported that the addition of ginger waste meal $(10,20,30$ and $40 \%)$ after extraction significantly increased the average daily feed intake of growing rabbits.

Feed conversion in groups P2, and P3 was improved by 6.56 and $8.47 \%$ respectively, while the performance index was increased by 13.34 and $20.03 \%$ respectively, in comparison with those of the control group (C). Rabbits fed diet P4 (1\% ginger) showed significantly $(\mathrm{P}<0.01)$ the highest feed conversion $(4.74)$ and the lowest performance index (33.74). The higher feed conversion ratio and lower performance index observed in group fed diet contained $1.0 \%$ ginger (P4) may be due to the lower live body weight and higher feed consumption obtained in this group (Table 2). Ali et al. (2008) and Kota at al. (2008) reported that the diet ginger addition significantly decreased the digestibility of crude protein and crude fat due to the negative effects of its compounds such as polyphenolics which significantly decreased the live body weight of growing rabbits. Also, Ademola et al. (2009) reported that ginger addition significantly decreased the abdomen fat and serum total protein, total lipids and cholesterol of broiler chickens which may lead to lower body weight gain. The basil supplementation (P1) insignificantly affected daily weight gain, daily feed consumption, feed conversion and performance index, comparing with the control group (C). These results are in contrast with those of Mona et al. (2009) and Rabia (2010) who reported that the addition of $3 \mathrm{~g}$ of basil/ $\mathrm{kg}$ diet in broiler diets significantly increased the live body weight, feed efficiency and feed intake. Rabbit's viability\% up to 13 weeks of age was affected by the supplementation with different medical and aromatic plants in growing rabbit diets. The rabbits fed the control or P3 (fennel) diets recorded 100\% viability, while those fed diet P2 (chamomile), P1 (basil) and P4 (ginger) recorded 87.5, 75 and $62.5 \%$ viability, respectively. Increasing the mortality rate in group fed diet containing $1 \%$ ginger (P4) may be due to the lowering abdomen fat in this rabbits which led to 
significant decrease in daily body weight gain and final live body weight. Ademola et al. (2009) showed that ginger addition increased the mortality rate in broiler chickens. El-Hosseiny et al. (2000) reported that the addition of chamomile in does diets $(60 \mathrm{mg} / \mathrm{kg} \mathrm{BW})$ reduced mortality rate of born kids to zero during the suckling period. This suggests that chamomile may have a role in improving immunity and performance of born kids. Pinheiro et al. (2004) mentioned that fennel and caraway seeds may be have an essential role in reduced mortality rate by their role in modify $\mathrm{pH}$ of rabbit digestive tract promoting useful bacteria and inhibit the harmful ones. Omer et al. (2013) reported that adding $0.5 \%$ fennel seeds significantly decreased the mortality rate of growing rabbits.

\section{Economical efficiency:}

Results of economical evaluation of rabbits as affected by the supplementation are shown in Table 2. Feed cost $/ \mathrm{kg}$ gain of fennel supplementation diet (P3) was lower than those of the control or other experiment groups. The economical efficiency value in rabbits fed diet (P3) was higher than those fed the control diet $(\mathrm{C})$ by $11.55 \%$. However, the highest economical efficiency value (151.79) was found with group fed diet P3 supplemented with $1.0 \%$ fennel. The $1.0 \%$ chamomile supplementation did not improve the economical efficiency\% comparing with the control group (136.14 and 136.08, respectively). On the other hand, the $1.0 \%$ supplementation with basil or ginger (P1 and P4) decreased the economical efficiency\% than those of the control group. These results agreed with those findings by Radwan and Khalill (2002) and Hanna et al. (2008). The results are in contrast with those of Abaza et al. (2003) who reported that the best relative economical efficiency was recorded with chamomile supplementation diet.

\section{Digestibility coefficient of nutrients, nutritive value and nitrogen utilization}

The digestion coefficient of nutrients and nutritive values of the experimental diets are shown in Table 3. Results showed that dietary supplementation with $1 \%$ fennel or chamomile (P2 and $\mathrm{P} 3)$ positively affected all digestion coefficient values of nutrients. Significantly $(\mathrm{P}<0.05)$ the highest $(\mathrm{P}<0.05)$ crude protein $(\mathrm{CP})$, crude fiber $(\mathrm{CF})$, ether extract $(\mathrm{EE})$ and nitrogen free extract (NFE) digestibility values were obtained in group fed diet supplemented with $1.0 \%$ fennel (P3), followed by diet (P2). The CP, CF, EE and NFE digestibility in group fed diet $\mathrm{P} 3(1.0 \%$ fennel $)$ was significantly $(\mathrm{P}<0.01)$ increased by $5.91,1.58,6.11$ and $5.31 \%$ respectively, than those of the control group. The rabbit diet supplementation with $1 \%$ ginger (P4) significantly $(\mathrm{P}<0.01)$ decreased the $\mathrm{CP}, \mathrm{CF}$ and $\mathrm{EE}$ digestibility than those of the control diet (C). These results are generally in accordance with those obtained by Underwood 
and Suttle (1999) and Mahady et al. (2005) who reported that the addition of medical and aromatic plants in growing rabbit and poultry diets significantly improved the digestibility coefficients. The improvement in digestibility coefficients resulted in elevating nutritive values of groups supplemented with $1.0 \%$ fennel or chamomile. The highest DCP, TDN and ME values were significantly $(\mathrm{p}<0.05$ or 0.01$)$ obtained in groups fed diets supplemented with $1.0 \%$ Fennel and chamomile (P3 and P2) (Table 3). Rabbits fed the P4 diet (1\% ginger) showed significantly the lowest digestibility coefficients and nutritive values among the other experimental groups. The N-Balance was significantly $(\mathrm{p}<0.05)$ increased by 37.36 and $24.73 \%$ in groups fed diets P3 and P2 respectively, as compared with the control group (C). The beneficial effects of fennel and chamomile supplementation on nutrients digestibility and hence on nutritive values as DCP, TDN and ME were found by previous authors as Moura et al. (2005); Janz et al. (2007); El-Bordeny et al. (2008); and Omer et al. (2013).

\section{Chemical composition of soft and hard feces:}

The chemical composition of soft and hard feces is shown in Table 4. Crude protein content of the soft feces was significantly $(\mathrm{P}<0.01)$ higher in rabbits fed diets supplemented with 1.0\% fennel, chamomile and basil (groups P3, P2 and P1) by $16.86,10.69$ and $9.49 \%$ respectively, while, they significantly $(\mathrm{P}<0.01)$ decreased in the hard feces by $11.65,6.81$ and $10.77 \%$ respectively, comparing with the control group (C). No significant differences in DM, EE and ash content of the soft feces where obtained between the control and experimental groups. On the other hand, CF content of the soft feces in group fed diet P3 $(1.0 \%$ fennel) was significantly $(\mathrm{P}<0.05)$ lower comparing with those fed the control diet (C) by $19.11 \%$. No significant differences were obtained in the chemical composition of hard feces between rabbits fed the control and the other experimental diets except the DM content. Results obtained of the chemical composition of soft feces may indicate that dietary supplementation with $1.0 \%$ fennel, chamomile and basil (groups P3, P2 and P1) activate the useful microorganisms in cecum and colon, producing high $\mathrm{CP}$ content in soft feces and improving the nutrients digestibility, especially for CF (Table 4).

\section{Carcass parameters and internal organs:}

The results of carcass traits and internal organs are presented in Table 5. Results showed that the most carcass traits and internal organs as a percentage of preslaughter weight were significantly affected by the dietary supplementation with medical and aromatic plants used. Hot carcass weight was significantly $(\mathrm{P}<0.01)$ increased in groups fed $\mathrm{P} 3(1.0 \%$ fennel $)$ and $\mathrm{P} 2$ (1.0\% chamomile) diets by 15.77 and $9.93 \%$, respectively, than those fed the control diet (C). On the other hand, the highest dressing\% was obtained in 
group fed P3 diet (1.0\% fennel) $(61.36 \%)$, while the lowest was obtained in group fed P4 diet (1.0\% ginger) (56.24\%). Ibrahim et al. (2000) reported that sweet basil or oregano at the level of $0.5 \%$ significantly increased dressing and giblets. In general, alimentary tract weight (full and empty) was insignificantly affected by the dietary supplementation with $1.0 \%$ basil, chamomile or fennel, while, the supplementation with $1 \%$ ginger significantly $(\mathrm{P}<0.01)$ increase the alimentary tract weight (full and empty) than those of the control group. The giblets weight as \% of the body weight was insignificantly affected by the supplementation of medical and aromatic planets used, except the liver weight, which significantly $(\mathrm{P}<0.05)$ increased by the supplementation. These results are in general agreement with those obtained by Radwan and Khalill (2002) and Hassan et al. (2004) who found that the carcass data differed between treatment upon feeding diets with medical and aromatic plants.

\section{Blood plasma constituents:}

The data obtained of some blood plasma constituents are shown in Table 6 . The results revealed that the concentration of plasma albumen, globulin Got, GPT, cholesterol and total lipids were significantly $(\mathrm{P}<0.01)$ affected by feeding diets supplemented with the medical and aromatic plants used. Plasma albumin in groups fed diets P3 and P1 (1.0\% fennel and basil) was significantly $(\mathrm{P}<0.05)$ higher by 14.11 and $8.06 \%$, respectively, than those fed the control diet (C). The highest plasma globulin was significantly $(\mathrm{P}<0.05)$ obtained in group fed diet $\mathrm{P} 2$ (1.0\% ginger), while, no significant differences were obtained between those fed the control and other experimental diets. The plasma total lipids and cholesterol were significantly $(\mathrm{P}<0.05$ and 0.01$)$ lower in rabbits fed diets $\mathrm{P} 3$ and $\mathrm{P} 4(1.0 \%$ fennel and ginger) than those fed the control or the other experimental diets. Similarly, Bhandari et al. (1998) and Hanna et al. (2008) reported that the supplementation of diets with fennel or ginger had significant effects on lowering the level of serum total lipids and cholesterol of either chickens or rabbits and this effect was positively related to its level in the diets. Group fed P3 (1.0\% fennel) present the lowest $(\mathrm{P}<0.01)$ GOT (45.56) and highest GPT (83.05). In addition, the plasma total protein, urea and creatinen were insignificantly differed between the control and other experimental groups. Furthermore, Gujaral et al. (1978); EL-Nattat and EL-Kady (2007); Ali et al. (2008) and Hanna et al. (2008) reported that the blood parameters were significantly differed by the supplementation of animal diets with medical and aromatic plants.

Conclusively, it is concluded that the supplementation of growing rabbit diets with $1.0 \%$ fennel or chamomile caused relatively considerable improvement in the growth performance without negative effects on carcass characteristics and constituents of blood plasma. Meanwhile, 1.0\% fennel supplementation in growing rabbit diets resulted in the best economical efficiency $(\%)$. 


\section{REFERENCES}

Abaza, I. M.; Asar, M. A.; El-Shaarrawi, G. E. and Hassan, M. F. (2003). Effect of using Nigella seed, Chamomile flower, Thyme flower and Harmala seed as feed additives on performance of broiler. Egypt. J. Agric. Res., 81 (2): 735-749.

Ademola, S. G.; Farinu, G. and Babatunde, G.M. (2009). Serum lipid, growth and haematological parameters of broilers fed garlic, ginger and their mixtures. World J. Agric. Sci., 5: 99-104.

Ali, B. H.; Blunden, M.; Tanira, O. and Nemmar, A. (2008). Some phytochemical, pharmacological and toxicological properties of ginger (Zingiber officinale Roscoe): A review of recent research. Food Chem. Toxicol., 46:409-420.

A.O.A.C. (1990). Official Methods Of Analysis. 15 ${ }^{\text {th }}$ Edition. Association of official Analytical Chemists, Washington D.C.

Armstrong, W. D. and Carr, C. W. (1964). Physiological chemistry: Laboratory Directions. $3^{\text {rd }}$ ed. P.75, Baburges Co. Minneapolis. Minnesota., U.S.A.

Bhandari, U.; Sharma, J. N. and Zafar, R. (1998). The protective action of ethanolic ginger (Zingiber officinale) extract incholesterol fed rabbits. $J$. Ethnopharmacol; 61:167-71.

Blasco, A.; Ouhayoun, J. and Masoero, G. (1992). Status of rabbit meat and carcass: Criteria and Terminology. Options Mediterranean's- Series Seminaries, No 17: 105 - 120.

Carabaño, R.; Fraga, M.J.; Santoma, G.; and DeBlas, J.C. (1988). Effect of diet on composition of cecal contents and on excretion and composition of soft and hard feces of rabbits. Journal of Animal Science, 66: 901-910.

Caspar Wenk (2003). Herbs and Botanicals as Feed Additives in MonogastricAnimals. Asian-Aust. J. Anim. Sci., Vol. 16, No. 2: (282-289).

Chabrol, E. and Charonnat, R. (1973). Method for determination of total lipids. Press. Medical. , 45: 1713.

Cheeke, P. R. (1987). Rabbit Feeding And Nutrition. Academic Press, Orlando, Florida.

Cheeke, P. R.; Patton, N. and Templton, G. S. (1982). Rabbit Production. $5^{\text {th }}$ Edition. The Interstate Printers and Publishers. Danville II.

Cross, D. E.; Mc Devitt, R.M.; Hillman, K. and Acamovic, T. (2007). Effect of herbs and their associated essential oils on performance, dietary digestibility and gut microflora in chickens from 7 to 28 days of age. Brit. Poult. Sci. 48: 496-506.

Duncan, B.D. (1955). Multiple Ranges and Multiple F. Test. Biometrics, 11: 142. 
El-Bordeny, N. E.; El-Ashry, M. A.; Khattab, H. M. and El-Sayed, H. M. (2005). Effect of some medicinal herbs on buffalo calves performance from first week old till weaning. Egyptian J. Nutrition and Feeds, 8 (1): 155.

El- Hosseiny, H. M.; Allam, S. M.; El-Saadany S. A.; Abdel-Gawad, A. M. and Zeid, A. M. (2000). Medicinal herbs and plants as feed additives for ruminants. 2-Effect of using some medicinal herbs on growth performance of Zaraibi kids. Proc. Conf. Anim. Prod. Sakha, Kafr ElSheikh, 18-20 April, p:189

El-Kerdawy, D. M. (1997). Olive pulp as a new energy source for growing rabbits. Egyptian Journal of Rabbit Science. 7, (1): 1 - 12

EL-Nattat, W.; Sand EL-kady, R. I. (2007). Effect of Different Medicinal Plant Seeds Residues on the Nutritional and Reproductive Performance of Adult Male Rabbit. International Journal of Agriculture \& Biology, 3: $1560-8530$.

Gujaral, S.; Bhumra, H. and Swaroop, M. (1978). Effect of ginger oleoresin on serumand hepatic cholesterol levels in cholesterol fed rats. Nutrition Reports International, 17: 183-187.

Hanna, M. F.; Samia Z. Meshreky and El-Zaiat, A. A. (2008). Effect of some supplementation medicinal plant on growth performance, carcass traits and economical efficiency of growing rabbits. Anim. Prod. Dept., Fac. of Agric., Cairo Univ., 29-30 Oct., Nutrition \& Feeds.

Hassan, I. I.; Askar, A. A. and EI Shourbagy, L. (2004). Influence of some medicinal plants on performance, physiological and meat quality traits of broiler chicks. Egyptian Poultry Sci., 24: 247-266.

Huang, Y. F.; Ma, H. L., Wu, D. F.; Zhou, J. I.; Zhou, K. S. and Qi, Z.Y. (1992). Effect of Chinese medicinal herbs additives on the growth of broilers. J. Fujian Agric. College, 1: 93-96.

Ibrahim, S. A.; El-Ghamry, A. A. and El-Mallah, G. M. (2000). Effect of some medicinal plants of Labiatae family as feed additives on growth and metabolic changes of rabbits. Egyptian J. of Rabbit Science, 10 (1): 105-120.

Janz, J. A. ; Morel, P. C.; Wilknson B. H. and Purchas R. W. (2007). Preliminary investigation of the effects of low-level dietary inclusion of fragrant essential oils and oleoresins on pig performance and pork quality. Meat Sci., 75: 350-355.

Kalogen, U.A. (1985). Rabbit Feeding. Agropromozdat Publishing, Moscow, Russia, 112 PP. (In Russian). 
Kota, N.; Krishna, P. and Polasa. K. (2008). Alterations in antioxidant status of rats following intake of ginger through diet. Food Chem., 106: 991996.

Mahady, G. B.; Pendland, S. L.; Stoia, A.; Hamill, F. A.; Fabricant, D.; Dietz, B. M. and Chadwick, L. R. (2005). In vitro susceptibility of Heli cobacterpylori to botanical extracts used traditionally for the treatment of gastrointestinal disorders. Phytother. Res., 19: 988-991.

Mona S. El-kutry; Hoda S. Ibrahim; Effat A. Affifi; El-Tellaw, M. and Dalia A. Zidan (2009). Effect of Dietary Sweet Basil and Fennel on Utilization of Calcium in Adult Rats. Am. Eurasian J. Sustain. Agric., 3(4): 784-796

North, M. O. (1981). Commercial Chicken. Production Manual. $2^{\text {nd }}$ Ed. AVI publishing Co. INC., Westpost Connicticut, USA.

Moura, L. S.; Carvalho, R. N.; Stefanini, M. B.; Ming, L. C. and Meireles, M. A. (2005). Supercritical fluid extraction from fennel (Foeniculum vulgare): global yield, composition and kinetic data. The Journal of Supercritical Fluids, (35): 212-219.

Pinheiro V; Alves A.; Mouro J. L.; Guedes C. M.; Pinto L.; Spring P. and Kocher, A. (2004). Effect of mannan oligosaccharides on the ileal morphometry and cecal fermentation of growing rabbits. $8^{\text {th }}$ World Rabbit Congress, Publa, Mexico.

Omage, J. J.; Onimisi, P. A.; Adegbite, E. K. and Agunbiade, M. O. (2007). Effect ofGinger (Zingiber officinale Roscoe) WasteMeal on Growth Performance, CarcassCharacteristics, Serum Lipid and SerumCholesterol Profiles of Rabbit. Pakistan. J. Nutr., 6, (4): 359-362.

Omer, H. A.; EL-Nomeary, Y. A.; EL-Kady, R. I.; Azza, M.; Badr, M.; Ali, F. A.; Sawsan M. Ahmed; ELAllawy, H. M. and Ibrahim, A. M. (2013). Improving the Utilization of Rabbit Diets Containing Vegetable Oil by Using Fennel (Foeniculum vulgare) And Oregano (Origanum vulgare L) as Feed Additives. Life Sci. J., 10 (1): 2625-2636 (ISSN:10978135). http://www. Life science site. com. 307.

Rabia J. Abbas (2010). Effect of using fenugreek, parsley and sweet basil seeds as feed additives on the performance of broiler chickens. International Journal of Poultry Science, 9 (3): 278-282, 2010

Radwan, M. S. and Kkhalil, E. F. (2002). Nutritional evaluation of Fennel hay inclusion in rabbit diets. Egyptian Journal of Rabbit Science, 12 (1): 85-94.

SAS (2004). SAS Institute. 2004. SAS Software. 9.1 ed. SAS Institute Inc., Cary, NC. 
Skomorucha, I. and Sosnowka-Czajka, E. (2013). Effect of water supplementation with herbal extracts on broiler chicken welfare. Annals of Animal Science, Vol. 13, no. 4, p. 849-857.

Srinivas N. Satyanarayana and Basil D. Roufogalis. (2008). Protective Effects of Ethanolic Extract of Zingiber officinale Rhizome on the Development of Metabolic Syndrome in High-Fat Diet-Fed Rats. Journal compilation (C) 2009 Nordic Pharmacological Society Basic \& Clinical Pharmacology \& Toxicology,104: 366-373

Underwood, E. J. and Suttle, N. F. (1999). The Mineral Nutrition of Livestock. 3rd Edition, CAB International Publishing.

Watson, D. (1960). Methods for determination of cholesterol. Clin. Chem. Acta, 5: 637.

\section{تاثير أضافة بعض النباتات الطبية والعطرية إلى علائق الارانب النامية

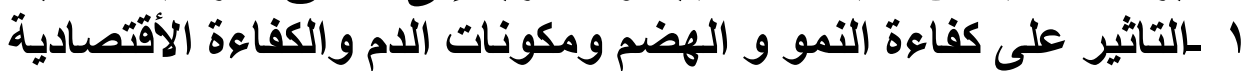

$$
\begin{aligned}
& \text { منير محمود العدوى'، محمد حسن خضير'، زهراء رمضان ابو العز '، اميمة عطا } \\
& \text { قسم الأنتاج الحيواني و السمكي ـ كلية الزر اعة ـ جامعة الإسكندرية ـ الإسكندرية ـ } \\
& \text { r معهد بحوث المصل و اللقاحات البيطرية ـ العباسية ـ القاهرة ـ مصر. }
\end{aligned}
$$

تم إستخدام عدد أربعون من ذكور الار انب النيوزيلاندى عمر ستة أسابيع

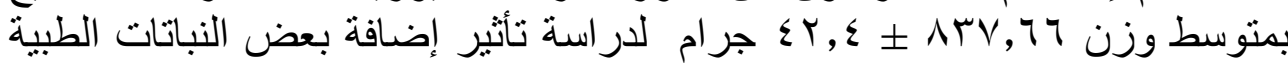

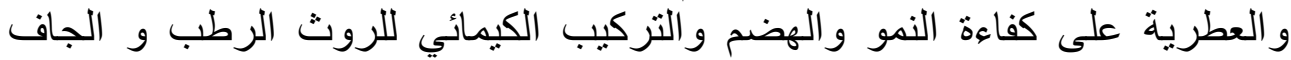

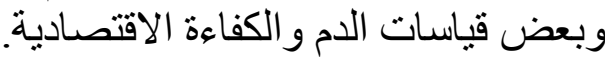

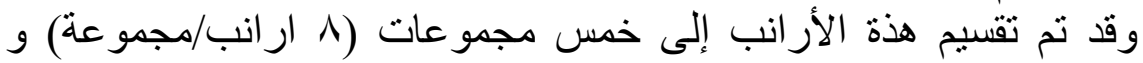
حفظت المجمو عة الاولى عليقة مقارنة بدون اضافات (كنترول) (C) في حين تم امداد التهاد

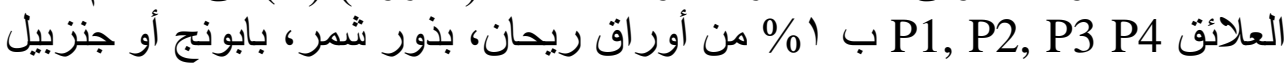

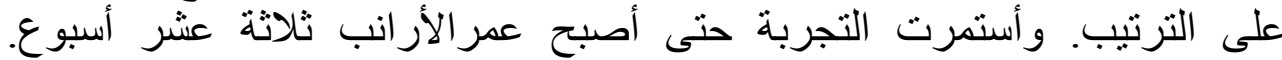
أوضحت النتائج أن هناك زيادة معنوية فى وزن الجن الجسم النهائى الحى ومعدل الزئ الزيادة

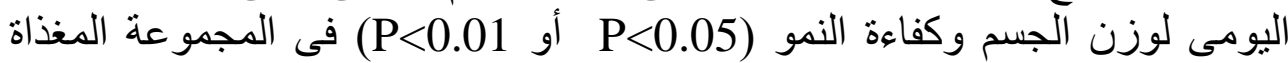

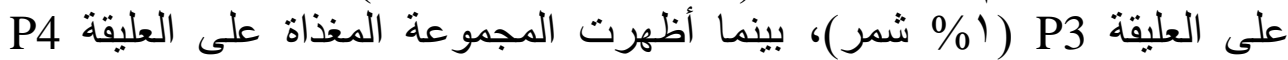


المحتوية على (1\% جنزبيل) أقل قيمة للقياسات السابقة. أيضا أوضحت نتائج

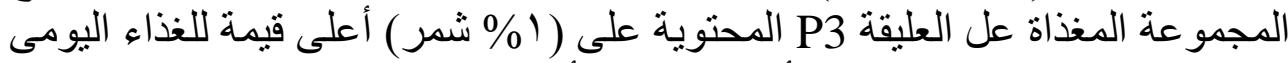

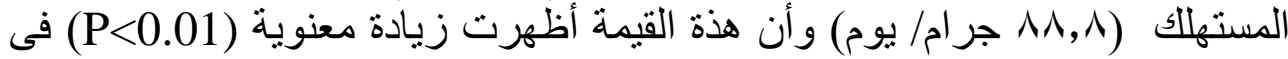

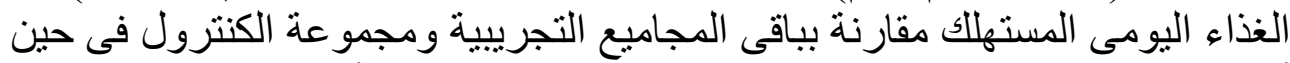

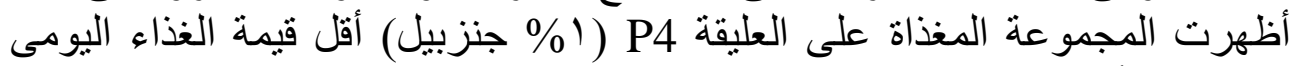

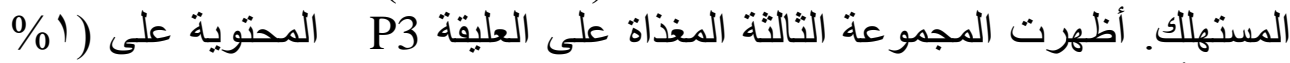

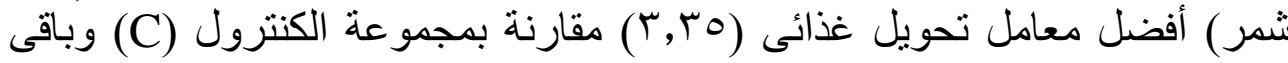

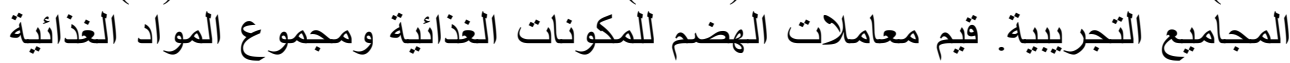

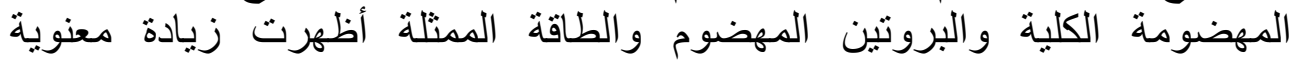

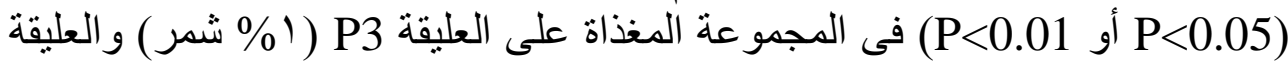

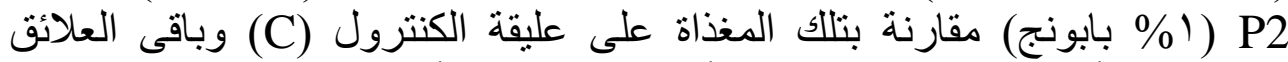

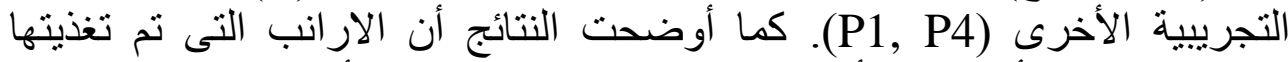

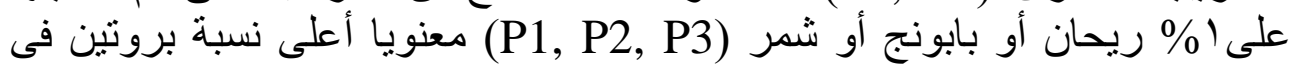

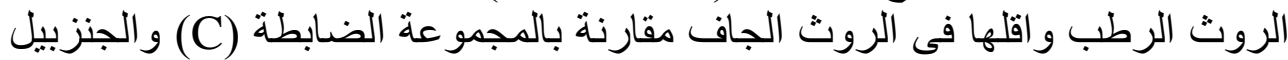

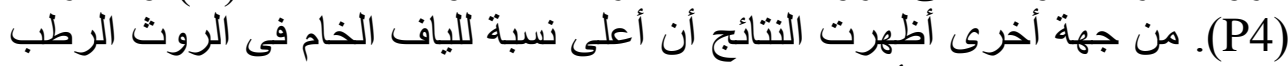

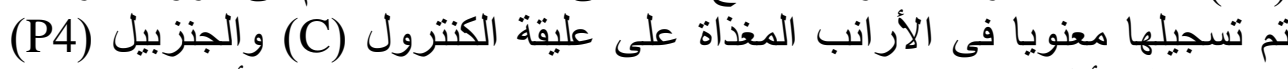

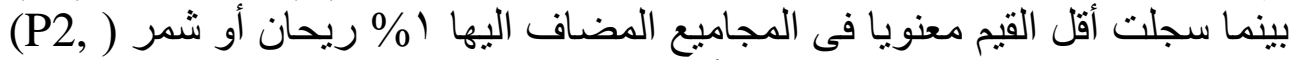

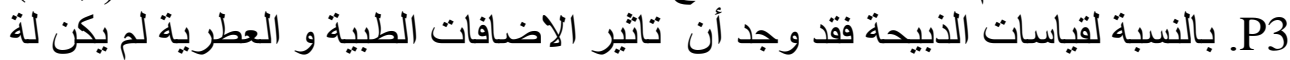

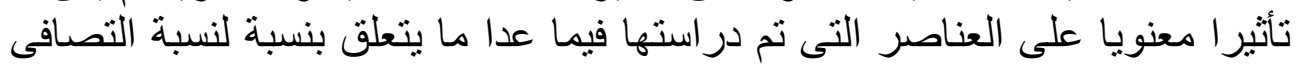

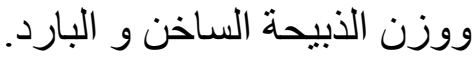

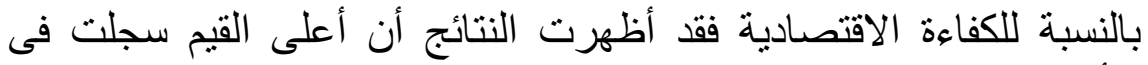

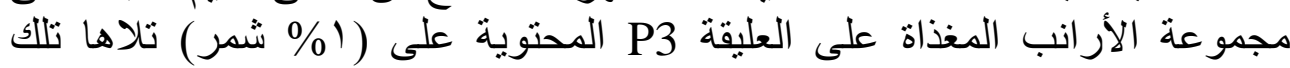

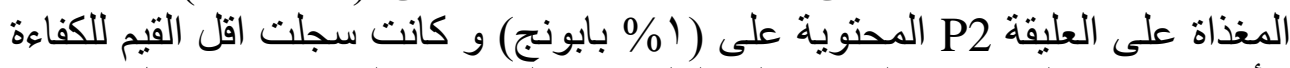

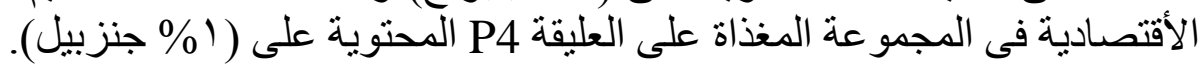

